This is an electronic reprint of the original article. This reprint may differ from the original in pagination and typographic detail.

Author(s): Haapakorpi, Arja; Saarinen, Taina

Title: $\quad$ Transnational turn and national models of higher education: The case of Finland

Year: $\quad 2014$

Version:

Please cite the original version:

Haapakorpi, A., \& Saarinen, T. (2014). Transnational turn and national models of higher education: The case of Finland. Nordic Studies in Education, 34(3), 187-200. https://doi.org/10.18261/issn1891-5949-2014-03-04

All material supplied via JYX is protected by copyright and other intellectual property rights, and duplication or sale of all or part of any of the repository collections is not permitted, except that material may be duplicated by you for your research use or educational purposes in electronic or print form. You must obtain permission for any other use. Electronic or print copies may not be offered, whether for sale or otherwise to anyone who is not an authorised user. 
Transnational turn and national models of higher education -- Case Finland

Arja Haapakorpi, University of Helsinki, Finland

Taina Saarinen, University of Jyvaskyla, Finland

Corresponding author:

Arja Haapakorpi

Palmenia Centre for Continuing Education

Helsingin alueyksikkö

Opetusala

PL 53 (Fabianinkatu 32)

00014 HELSINGIN YLIOPISTO

tel. $+358-50-4150548$

arja.haapakorpi@helsinki.fi 


\title{
Transnational turn and national models of higher education -- Case Finland
}

\author{
Abstract \\ The purpose of the article is to problematize the relationship between the Nordic democratic public \\ higher education tradition and transnational market driven knowledge economy policies. The article \\ illustrates this development with two cases -- quality assurance and internationalisation policies -- \\ where external demands, based mostly on market ideologies, have been introduced with apparently \\ transnational incentives but having national implementations. These transnational pressures are \\ related to a kind of soft governance of higher education policy, characterized by networked decision \\ making and use of expert consultants, which possibly promotes flexible decision-making and \\ efficiency, but may simultaneously produce adverse outcomes to transparent and democratic \\ decision-making.
}

Key words: higher education policy, outsourcing of policy, internationalization of higher education, quality assurance, English as medium of instruction

\section{Transnational trends and Nordic reactions}

The Nordic countries share a particular policy based on the idea of welfare society, social values, trust and a Nordic type of democracy (Jacobsson \& Lægreid \& Pedersen, 2003). Nordic countries are, according to many studies, high trust countries which are characterized by ethnic homogeneity, Protestant religious traditions, good government, wealth, and income equality (Delhey \& Newton, 2005).

Nordic higher education policy has traditionally complied with this ideology. Universities in the Nordic countries have been funded and controlled by the state and they have been tuition-free. Economic equity in Nordic higher education has not only been a value-based pattern, but also 
efficient and effective tool in labour, economy and social policies. Highly educated labour force promotes developments of the national economy and a stable and safe society with active and equal and active citizenship. For example, according to Jalava (2012), higher education in Finland has promoted the economy, well-being and opportunities for social mobility and, in addition, universities have been arenas for active political citizenship from the end of 60's to late 70's, during the expansion of universities and the related funding increase.

However, higher education policy in the Nordic countries has been changing in 2000's in ways that have conflicted with the Nordic political ideology to some extent. This transformation of higher education policy is related to many intersecting global tendencies, which are in turn reflected into national and local circumstances. The current environment of higher education is characterized by public funding crisis and related changes in university governance, massification of higher education, global markets of intellectual capital, transnational and national competition for funding, prestige and students, intergovernmental higher education policy and related assessment methods and control measures. All these developments have lead to an "outsourcing” of higher education policy, characterized by an acknowledgement of the multiple interest groups by enforcing policy network, de-politicizing questions on higher education (see Saarinen \& Pöyhönen, 2009), and promoting decision making outside the Parliament by using methods of open consultation and crowdsourcing (see for instance Aitamurto 2012).

With these tendencies, doubts have been cast on sustainability of the qualities in higher education in Nordic countries as regards to economic equity, well-being and opportunities for social mobility. For instance in Finland, trust in the academic community has, until the recent legislative reform of 2010 (see Rinne \& al. in this issue) clearly formed the basis for organizing universities, as university management has been based on disciplinary and collegial practices, the bulk of power admittedly having rested on the professorial and other research and teaching staff. In recent studies, however, Finnish academic staff has shown concern about losing their opportunities for active 
political citizenship in universities under new policy, governance and funding sources. (See Rinne \& al., 2012.)

Our article focuses on this nexus of the Nordic democratic public higher education tradition and the transnational market driven knowledge economy policies. We look into whether and how this transnational trend of marketisation and soft governance is realised or becomes visible on the national level, and how it is being reacted to in a national setting. How has Finnish higher education reacted to the transnational tendencies of marketization and outsourcing of higher education policy? What is the position of "the national" in transnational higher education policies? What are the dynamics that influence the position of the national system?

We use Finland as an example of how Nordic higher education institutions have reacted to intersecting national and transnational tendencies on new modes of governance methods, funding organization, competition and marketization. First, we discuss internationalisation (border crossing activities between national systems; Teichler, 2004), globalization (border crossing activities between blurred national systems; Teichler, 2004) and transnationalisation (“integrated arrangements transcending relations between state actors”; Beerkens 2004, 15). We take as a starting point a theoretical discussion on global economy to provide an extensive perspective for our study. The discussion then leads us to the crucial tendencies, which currently change the landscape of higher education in Nordic countries.

We approach our question via two cases which are based on our previous and current individual research projects: quality assurance policies on one hand, as an example of an explicit and penetrating policy particularly in Europe (Haapakorpi, 2011; Haapakorpi \& al., 2013 ), and language policy on the other hand, as an example of a more implicit policy that appears in context with internationalisation and knowledge society policy discourses (Saarinen forthcoming; Saarinen \& Nikula, 2013; Saarinen \& Taalas, forthcoming). 
While the issue at hand concentrates on Finland as one example of the Nordic welfare nation states, the approach of focusing on multi-sited higher education language policies is by no means limited to that geographical context: similar trends are seen in all globalizing Western countries.

\section{Domestication of global tendencies -- reshaping national higher education policy in Nordic countries}

It has been claimed that with increased globalization, the role of nation states would diminish. However, even from the perspective of economic globalization, this might not totally be the case. Dani Rodrik (2011) has proposed that (economic) globalization has, probably against earlier expectations (and fears even), in fact strengthened the need for strong national systems. Unregulated globalisation of the world economy is related to many socially and economically unfair and damaging tendencies, but, according to Rodrik, it also damages transnational commerce in the long run (Rodrik, 2011, pp. 200-220). Simultaneously, however, it creates a need for a nation state that promotes rigid economic rules and in some ways chokes democratic decision making. Establishing international agencies to control and negotiate rules for the global economy is not based on citizenry but on interest groups and fragmented and casual groups of citizens (Rodrik, 2011, pp. 190-202). To preserve an option for democratic decision-making at national level, national sovereignty would need to be protected (Rodrik, 2011, pp. 70-75).

Many of these tendencies are easily recognised in higher education. The weight of national higher education policy has changed with the global tendencies, but this does not necessarily mean that the nation state would have no role in higher education. Because of the current funding crisis and earlier changes in funding patterns of publicly funded universities, non-public funding is becoming more common. While Nordic countries still recognize the national role of the higher 
education system in providing tuition to fulfil national needs, the principle of tuition-free education is not necessarily taken for granted anymore. Furthermore, the legal status and position of universities have changed in every Nordic country and the reform of governance has transformed their relations to the state and other governing agencies (Ikenberry, 2009; Rinne \& al., 2012).

What, then, about the role of nation state in globalization? Universities as institutions have been defined both as intensely international and inherently national. This is a cliché much like the uncritical assumption of globalization abolishing the need and space for nation states. Universities are international in as much as their knowledge base is international: scientific disciplines and research have an international (or at least universal) basis (see Clark 1983 for a discussion on the fundamentals of disciplines). Organisationally, and with regard to their educational role, on the other hand, universities have been strongly national institutions with a role in nation building particularly in the first half of the 19th century, as first periods of massification of higher education in the 1800s broke the academic independence of universities and tied them more closely to the nation states and their knowledge and labour market needs (Scott, 2011; Jalava, 2012). In other words, universities are as much results of their disciplinary internationalisation as their organisational nationalism. While some of the formal and informal decision making powers have been shifted to international actors, as witnessed by Pan-European degree reforms and research cooperation, the nation state still holds a distinct role in higher education political decision making (Saarinen, 2008), particularly when it comes to national educational provision. As Marginson (2006) suggests, national and global can be seen as “distinct zones of competition”.

With the transnational turn, ideologies and policies have been spread and implemented that have challenged the Nordic political and cultural model based on economic equity and transparent democracy. In higher education, free and equal access to education and university management based on academics' decision-making have in recent years been questioned with arguments of transnational competition, decreasing funding and needs to comply with international standards. 
Higher education policy tends to be outsourced to external, soft (Kallo 2009) and networked actors, lessening the power of formal national decision making based on political debates and discussions on values and preferences (see Saarinen \& Pöyhönen, 2009; Veiga \& Amaral, 2006). Some examples of this are the Open Method of Coordination (Kröger, 2009; see also Krejsler et al. in this issue.), open consultation, networked policy making (Ball, 2012) and other forms of governance; in short, a lessening of hierarchical, formal, top down governing. These practices, while adopting tools like benchmarking and adoption of "best practices”, simultaneously de-politicise policy making either by transferring political decision making power to external actors like experts groups, or by presenting these forms of governance as neutral and rational instruments, devoid of political interests. For example, the Bologna goals were gradually agreed on by networks of agents of higher education management, experts, interest groups and policy makers (Veiga \& Amaral, 2006), and then imported in national systems. Taking up transnational policy models may appear effective ${ }^{1}$ when problems or goals are dealt with individually, one at a time, without regard for their intertwined nature. However, higher education goals and problems are inexplicably linked with other policies and challenges in the same or other sectors and, instead of focusing on single measures, extensive policy is needed (Veiga \& Amaral, 2006). This method may promote participation opportunities, but may simultaneously make the policy process more obscure, as it pushes the boundaries of higher education policy (partly) outside the public domain both nationally and transnationally.

Despite the "softness" (Kallo, 2009) of the internationalization agenda, it is still linked to strong transnational powers, such as the European Union strategies, the OECD, and other influential policy structures. From the perspective of democratic decision-making, outsourcing of policy making is dubious as the members of the networks and agencies are not elected in a democratic

\footnotetext{
${ }^{1}$ Outsourcing of policy has a history in project-based governance, which emerged two to three decades ago. Bureaucracy, institutionalized structures and patterns of governance were avoided by carrying out reforms by implementing short-term projects (Newman et al,. 2004). Project-based working was, in a sense, was a pre-season training for networking.
} 
process. The transnational agencies are accountable to their coordinating organizations, which, however, do not have any liability as regards to policy organization with a proper control power. In turn, soft governance or outsourcing of policy provides varied networks in universities, interest groups, politicians and students with wider opportunities to participate in higher education policy. In practice, soft governance does not promote democracy for all, as most of the participants are experts and members of interest groups.

All this has changed the nature of the dynamics of higher education in the Nordic countries. The position of external stakeholders in university governance has been strengthened, and respectively, collegial management has lost some of its foothold. Introducing external stakeholders in university boards and changing the nature of funding may mean that the nature of national steering of higher education changes from state-driven to market-driven, but it is nonetheless national. Although the differences between the Nordic countries have been increasing as regards to higher education policy, changes in the legal position and related consequences are common in all Nordic countries.

\section{The cases: Quality assurance and internationalization strategies -- convergences and divergences of international and national policies}

In the socio-cultural context of the Nordic countries, the benefits of adopting transnational policies and related patterns are not based on uncontested evidence. Marketization puts pressures on higher education policy, and this necessarily also has unintended and unwanted outcomes. Fragmentation of goals and measures as regards to long-term higher education policy seems to be the inevitable outcome. 
This article focusses on two implications of transnational policies -- quality assurance and internationalisation policies -- where external demands, based mostly on market ideologies of increasing the "attractiveness" of the higher education system, have been introduced with apparently transnational incentives but very national implementations.

Globalisation of higher education is related to marketization and competition, decreasing public funding and needs to comply with international standards. The global competition for funding, students, status and success in rankings have been introduced the higher education landscape (Altbach, 2011). Higher education systems are linked to transnational markets of higher education; funding is increasingly - transnationally competed and the mode of organising higher education follows increasingly international patterns. Higher education is increasingly a commodity and it is sold and bought across nation states (Amthor \& Metzger, 2011).

Our first case focuses on quality assurance related to the Bologna agreement. With massification of higher education, quality certifications and accreditations are expected to guarantee the sufficient quality of higher education provision for "customers", as the current market metaphor goes. Assessment agencies increasingly operate internationally in order to provide certifications that make national systems transparent and persuade also foreign students. University rankings provide resources for funding and reputation. Rankings can be seen as a transnational policy discourse, which contributes to convergence in higher education policies (Erkkilä, 2013). Quality accreditation or assessment can neither be ignored as they provide legitimation for higher education systems and institutions, which have economic and status-related effects. Rankings and quality assurance put pressure on convergence, but the consequences of ignoring them are, however, unknown, as sanctions are rare in the Nordic context. Quality assurance demands are complied with in order to avoid negative consequences.

Our second case, deals with the position of language -- particularly English in relation with the national language(s) -- in international student mobility. Increasing the strategic planning related to 
internationalization provides for another view into the relationship of national and transnational. In recent years, political demands for increased internationalization (defined as "border crossing activities between national systems of higher education” by Teichler, 2004) have challenged the traditional understanding of higher education as national. Several reforms have during recent years taken place from the point of view of the "international attractiveness" or "competitive edge” of higher education, linking internationalization to the problematics of quality assurance.

Simultaneously, internationalization and processes related to it challenge higher education dynamics from a series of viewpoints. Internationalisation, however, has in recent decades been promoted largely in relation to the nation state, as developing the position of national (educational, economic etc.) systems in increasing global competition. (see for instance Enders, 2004). In other words, as Enders puts it, internationalisation may even work as a kind of “icebreaker” for national reforms, as it gives new impetus to national debates on higher education reform.

In this article, internationalisation is analysed from the point of international study, and more precisely English as the lingua franca of international higher education markets. The OECD countries, and particularly the norm-providing “Inner Circle” (Kachru, 1997) English speaking countries Australia, USA and UK still dominate the international study markets (Marginson, 2006), but non-English speaking countries in Europe and Asia increase their supply of English language higher education (Brenn-White \& Faethe, 2013). Because of the declining public funding, universities in Nordic countries strive for getting funding from external sources. Exportation of higher education programs is assumed to be a promise for solving the funding crisis, which puts pressures on providing programs in English for commercial and prestige-based purposes. While Anglophone countries dominate the international study market regardless of their high fee policy, this hegemonic position may, however, gradually be changing.

\subsection{Quality assurance related to the Bologna agreement in Finland}


The Bologna agreement has aimed at the establishment of a common European Higher Education Area. Among other reasons, this was motivated by the aim of reinforcing European resources in the competition with the economic powers of North America and Asia (Amaral \& Vega, 2006). The participating states voluntarily committed themselves to the goals in a declaration actually signed outside the European Union institutions. In other words, the European Union does not have any legislative powers in the area of education, but it uses an intergovernmental method of decisionmaking on education policy.

However, higher education policy (without legislative power) has been motivated by promotion of economy and employment since the Lisbon agreement in 2000. Thus, the strategic goals of competitiveness and knowledge economy have been linked with education policy in Europe. In the Berlin meeting of 2003, the targets related to European Higher Education Area were clarified, as the Berlin Communiqué established quality assurance systems and two-level degree system and recognition of degrees. It was agreed that by 2005, a quality assurance system at institutional, national and European level would have to have been built up.

Haapakorpi (2011) studied the outcomes of quality assurance related to the Bologna goals in Finnish universities. In Haapakorpi \& al. (2013), a comparative study was introduced, which focused on the process of quality system assessment in Finnish and Icelandic universities. The aim here is to focus on the case Finland, but comparison with Iceland makes the most important findings in the subject area more visible.

In Finland, the system of audits was implemented in 2005. The implementation followed the goal of European Higher Education Area, and, thus providing possibilities for mobility for students and staff. The FINHEEC (the Finnish Higher Education Evaluation Assessment Council) started the piloting of audits. This development compelled Finnish higher education institutions to establish quality assurance systems. In Iceland, quality assurance was stipulated already in the Act of 1997 
and further enforced in a revised Act in 2006 when accreditation of universities was stipulated in line with the Bologna agreements and based on internationally accepted criteria. A National Qualifications Framework was stipulated and all universities were to apply for accreditation in 2008.

Assessment of higher education quality systems complies with shared guidelines across nation states, as the aim is to increase transparency of higher education institutions for mobility purposes. Thus, standardized methods and criteria are applied, although there are national and local differences in policy and implementation (Serrano-Velarde, 2008).

In both countries, passing the evaluation was important for the university institution. However, there were differences between the countries as regards utilizing opportunities and awareness of the meaning of passing it.

In Iceland, the result of accreditation was clearly recognized and related to the national context. The position and size of Iceland promoted the adopting of an international higher education quality system implementation. Iceland has been dependent on higher education exchanges with other countries, particularly with Northern America and other Nordic countries. Icelandic universities have not been able to provide higher education programs in all disciplines due to the small size of the country, and consequently the students have taken studies abroad. In addition, Icelandic universities have received students from abroad, including Northern American countries, where accreditation is the pattern of quality assessment in higher education. Accreditation as a standardized pattern of quality certification has made the student exchange fluent.

In Finland, in turn, the purpose and the status of the audits were unclear for the university staff in the first audits of 2005; the framework, purpose and utilization opportunities of quality assessment related to the Bologna goals were not recognized. In addition, there were no sanctions for not passing. Quality was indicated in universities by optional international evaluations focusing on research and education until 2005. Unlike Iceland, international student exchange was not 
remarkable in Finland, at least until 2005, and the goal of European higher education area was not recognized either.

In both countries, the Bologna-related quality assessment was applied in a way which also promoted national purposes for organizing higher education institutions, such as the purpose of establishing status and position for new higher education institutions. In higher education institutions, the management utilized quality system assessment for managerial purposes. However, the Nordic improvement oriented way of evaluating, which has been typical in Nordic countries (see Danø \& Stensaker, 2007), was applied to some degree.

The purpose and idea of the assessment procedure were in conflict with each other to some degree. The standardization related to quality assurance may have caused unintended and unwanted consequences. First, the resources for assessment were limited, which restricts the opportunities for a profound assessment of particular university institutions and across nation states. On the basis of the study, misunderstandings and false conclusions took place in complex multi-disciplinary and large universities. Second, national differences do matter: in Iceland, assessments were carried out in English and as there are various "Englishes”, non-native English speakers from several countries can enter misunderstandings. An indirect unintended outcome may be that university institutions begin to anticipate assessment and act in a way that ensures their passing the audit, which may interfere with consistent university policy. For example, assessments may promote unnecessary homogenization of universities, which may conflict with the goal of differentiation of university profiles. Third, poorly conducted transnational assessments cause crises of evaluation legitimacy. They are expensive and very time consuming and if they do not convince university staff that they are conducted in a highly professional manner, they are more likely to be waste of money (Haapakorpi \& al. 2013). In addition, the standardized assessment system may formalize higher education institutions in a way which does not take into account national and local needs. 
Quality assurance related to the Bologna goals was implemented on the basis of national needs in Finland, and improvement oriented evaluation, typical for Nordic countries, was applied. However, the utilization and application options were limited as the implementation of the Bologna goals was based on a standardized pattern of quality assessment. The aim was to provide transparent information and assessment on universities across nation states, and to promote student mobility and quality assurance by supplying information on the quality of higher education institutions. However. the outcome did not quite comply with the aim. The standardized assessment pattern does not guarantee equal and similar treatment as national higher education environments and quality agencies are different. Comparative research with Iceland confirmed these findings. The international evaluation organizations (such as ENQA), consisting of experts, contribute to regulating and counselling on assessment, but the variation of universities and national higher education systems cannot adequately be taken into account. On the national level, decision-making on quality assurance is outsourced and not included into discussions and disputes on higher education policy.

\subsection{International study market and the position of languages in Finnish higher education}

International mobility (of students and staff, both short and long term) is the most visible activity of internationalisation. International mobility is a huge economic commodity for English speaking countries (especially the United Kingdom, United States of America and Australia; Marginson, 2006), but also increasingly for non-English speaking countries (Hughes, 2008) particularly in Europe. Globally, students are flowing towards high-fee charging English speaking countries (see also Marginson, 2006), making internationalization a major global industry. OECD countries alone hosted approximately 1.6 million foreign students in 2001, one third of whom in the USA and an 
additional 25 per cent in the UK, Australia, Canada and New Zealand (Marginson, 2006). To combat this “Anglophone asymmetry” (Hughes, 2008), European countries have upped their English language provision by 38 per cent between 2011-2013 (Brenn-White \& Faethe, 2013).

Nordic universities are typical examples of non-Anglophone universities that offer increasing numbers of English language teaching at universities and polytechnics. However, internationalisation and processes related to it challenge Nordic higher education not only from the point of view of demands for foreign language (mostly English) teaching at universities and polytechnics, but also from the fundamental perspective of universities and polytechnics as national institutions providing a public service in the national languages in a globalizing world (see Marginson, 2006 for a discussion of the national - global interface in the Australasian context; Välimaa, 2005 for an historical and social dynamics view into Finnish higher education). Here, too, national solutions to international challenges differ even within the Nordic countries.

Firstly, student fee markets in Nordic countries have been designed in different ways in recent years. Denmark and Sweden have introduced study fees for non EU/EEA students (in 2006 and 2011 respectively), whereas Norway and Iceland have not done so. (Nordic Council of Ministers 2013). In both Denmark and Sweden, the number of international applicants decreased significantly after fees were introduced. In both countries, however, the number of applicants started to go up after a period of 1-2 years, although particularly in Denmark, the increase was due to a sharp increase in the numbers of EU/EEA students rather than non-EU/EEA students (Ministry of Education and Culture, 2013).

Finland has an ongoing experimentation with study fees for a restricted number of programmes in 2010-2014, but with rather conflicting results (Weimer, 2012). While 154 degree programmes registered for the experiment, only 41 actually collected fees in 2012, and in most programmes only from very few students (Ministry of Education and Culture, 2013). At the moment -- the experiment is still ongoing as this article is being written in January 2014 -- the future of the experiment seems 
difficult; on one hand the participants appear to assume that introducing fees for non EU/EEA students is an inevitable international trend, but on the other hand, there are several open questions that deal with practical issues of organising fee collection as well as more ideological issues of equity (Ministry of Education and Culture, 2013, 25-28).

Secondly, internationalization of cooperation further increases these pressures towards the language of tuition, as English increases its share as a language of tuition, previously dominated by the local Nordic languages. Here, as previous research shows (see issue 216, 2012 of International Journal for the Sociology of Language on language in the internationalisation of Nordic higher education), the Nordic countries have solved the issues of language in higher education in different ways, resulting in different kinds of dynamics. (B Saarinen \& Taalas, forthcoming.) Finnish higher education has an explicit national language policy, regulated by the Constitution, Language Act and University Act, which is reflected in higher education as monolingualism (Finnish or Swedish) or bilingualism (Finnish and Swedish) of individual institutions. Additionally, universities were required to draft their own language policies, as mandated in the Council of State Decision on development of education and research for the years 2007-2012.

Internationalization policies are potentially highly language intensive policy areas, but somewhat surprisingly, language is not politically visible in Finnish higher education internationalisation strategies (Saarinen, 2012). The position of English as an Academic Lingua Franca has not been universally questioned in the Nordic countries or very intensively problematized as a language of higher education internationalization.

However, there are differences between Nordic countries. Danish universities mostly rely on an institutional policy of “parallel languages”; i.e. using Danish and English “in relevant contexts” so that, ideally, neither Danish nor English becomes marginalised in Danish universities (Hultgren, 2013). Sweden, in turn, has introduced a new Language Act in 2009, which for the first time defines Swedish as the official language of the country. Finland, as a constitutionally bilingual country, 
provides an interesting case, where "foreign" is used euphemistically in the coinage "foreign language programmes” when in fact English is meant, implicitly making English the self-evident language of internationalization. Norway and Iceland have recently introduced legislation which strengthens or safeguards the position of the national language in international settings. In short, Finland is the only Nordic country which has in recent years in fact relaxed its legislation on the use of other than national languages, thus giving in to global pressures within higher education. On the other hand, national interests are promoted in the internationalisation strategies by economic arguments, rather than linguistic ones (see Saarinen \& Taalas, forthcoming). In other words - and to put it bluntly - in public policies, Finnish national interests are being promoted in the sphere of economic interests and there in English rather than Finnish (let alone Swedish, which is increasingly becoming the third wheel in Finnish universities, see Rontu \& Saarinen, 2013). The nature of "national” appears to be changing from the 19th century understanding of nation states having strong links with national languages particularly in European countries (see Anderson, 1990), to nation state’s higher education policies defined by their economic needs.

It seems that the area where language still is linked with Finnish nation state interests is language legislation, and more precisely, the Constitution, as witnessed most recently by three decisions by the Chancellor of Justice’s office in November 2013, where the complaints dealt specifically with the students' constitutional right to use Finnish also in English speaking degree programmes. On the other hand, English as an international language is in fact highly hegemonically national in that the international sphere of student mobility favours the traditional, hegemonic standards of English, namely the American, British, Australian, Irish, Anglophone Canadian and New Zealand varieties. Saarinen \& Nikula (2013) studied language requirements of Finnish universities and observed that in Finnish higher education, not only the hegemonic "inner circle” (Kachru, 1985) varieties are preferred, but in many cases also students with an English language first cycle degree in English from another European or Nordic country was exempt from 
taking an English test before entry in a Finnish university or polytechnic. While this

operationalisation of necessary skills is a practical requirement, it also makes language

requirements a political, rather than a linguistic requirement, and seems to be indicative of higher

education rather than language education policies, as the European countries apparently find each

others' HE systems and language testing more reliable than those structures in, for example, Africa or Asia.

However, while the inner circle varieties from the UK, USA and Australia still continue to have a dominating position in the HE internationalization field, other varieties (both native and nonnative) are beginning to challenge this position (see Brenn-White \& Faethe 2013). It seems that countries where “expanding circle” (Kachru, 1997) varieties of English (i.e. English not as first or second but foreign language), are not only gaining in market share but also in prestige. This would, in turn, imply a strengthening of smaller (non-English speaking) national systems at the expense of larger and globalised (English speaking) ones.

In conclusion, while it appears that the concepts of national changed its meaning towards a more economic understanding, the question of whether the role of national higher education has diminished or merely changed its nature is more complex.

\section{Conclusions}

Institutional patterns related to transnationalization put pressures on higher education systems and institutions to converge their activities. Simultaneously, national higher education policies tend to either conform to these policies or diverge into their own directions. Our examples from quality assurance and internationalisation policies show that the effect of transnational policies on national ones is by no means simple and one-directional. Internationalization takes place in an economic, 
institutional and political setting, which partially promotes outsourcing of decision-making to nongovernmental networks and and implementation of hidden, non-democratic patterns. Policy reforms also tend to produce unintended consequences. As quipped by Finnish historian of higher education Marja Jalava (2012), this also seems to be the case in historical perspective: university reforms often tend to result in "something that has not been intended by any of the parties involved". Dani Rodrik's observation in respect to the importance and persistence of national institutions applies also for higher education; if nation states are necessary for controlling the global economy, the same appears to be true for higher education (see Saarinen, 2008; Marginson \& van der Wende, 2009).

However, while the national level seems to retain its significance, its nature appears to be changing: "national” no longer equals "state driven” or "public” even in Nordic countries. If (national) higher education policy making is outsourced into networks of institutions and individual experts, what does this mean from the point of view of democratic decision making and transparency? How are the members of these networks chosen, as they are usually neither elected by peers, nor act as civil servants in the service of the public sector? Although networks are not permanent institutions, the social bonds between the members are not casual, but constructed on the basis of former networks. Also, the emergence of networks is invisible for outsiders, which makes it difficult to contribute on them. From the perspective of applying all the possible expertise and the means of democratic decision-making at the national level, network-based soft governance is not unproblematic.

International cooperation and collaboration is potentially a great source of beneficial development for higher education systems and patterns. However, a particular consideration is needed when standardization is the aim of the cooperation. Higher education is of primary importance for Nordic welfare societies and the national governance and policy does not only mean democratic affiliation and responsibility, but also opportunities to control the outcomes of policymaking. The current global tendencies are, however, influential, and finding the nationally 
meaningful ways to cope with them is a challenge higher education systems will have to tackle from a national perspective.

\section{Acknowledgements}

Part of this article is based on an Academy of Finland project nr. 138287

\section{References}

Aitamurto, T. (2012). Crowdsourcing for Democracy: New era in policy-making. Committee for the future, Parliament of Finland 1/2012. Retrieved from http://web.eduskunta.fi/dman/Document.phx?documentId=aj31112105519943\&cmd=download

Altbach, P. (2011). The Past, Present and Future of the Research University. Economic \& Political Weekly, 14(16), 65-73.

Amthor, R. \& Metzger, S. (2011).Neoliberalism, Globalization, and the American Universities in Eastern Europe: Tensions and Possibilities in 'Exported’ Higher Education. Globalizations 8(1), 6580.

Anderson, B. (1991). Imagined Communities. Reflections on the origin and spread of nationalism. Second edition. London: Verso.

Ball, S. (2012) Global education inc. New policy networks and the neoliberal imaginary. MiltonPark: Routledge.

Beerkens, H. 2004. Global Opportunities and Institutional Embeddedness; Higher Education Consortia in Europe and Southeast Asia. PhD dissertation, University of Twente. Retrieved from 
http://www.utwente.nl/mb/cheps/phdportal/cheps\%20alumni\%20and\%20their\%20theses/thesisbeer

kens.pdf

Brenn-White, M. \& Faethe, E. (2013). English-taught Master’s programs in Europe: A 2013 update. September 2013. Institute of International Education. Retrieved from http://www.iie.org/Researchand-Publications/Publications-and-Reports/IIE-Bookstore/English-Language-Masters-BriefingPaper-2013-Update

Clark, B. (1983). The Higher Education System: Academic Organization in Cross-National Perspective. University of California Press.

Darmanin, M. (2009). Further and higher education markets’ cushions: portability of policy and potential to pay. International Studies in Sociology of Education, 19 (3-4), 175-201.

Delhey, J. \& Newton, K. (2005). Predicting Cross-National Levels of Social Trust: Global Patterns or Nordic Exceptionalism? European Sociological Review, 21(4), 311-327.

Danø, T. \& Stensaker, B. (2007). Still Balancing Improvement and Accountability? Developments in external Quality Assurance in the Nordic Countries 1996-2006. Quality in Higher Education, Vol. 13 (1), 81-93.

Erkkilä, T. (2013). Global University Rankings, Transnational Policy Discourse and Higher Education in Europe. European Journal of Education. 20 November 2013. doi: 10.1111/ejed.12063 
Gorman, E. \& Sandefur, R. (2011) . Golden Age, Quiescence, and Revival. How the Sociology of Professions Became the Study of Knowledge-Based Work. Work and Occupations 38(3), 275-302.

Haapakorpi, A. (2011). Quality Assurance Processes in Finnish Universities - Direct and Indirect Outcomes and Organizational Conditions. Quality in Higher Education 17, 69-82.

Haapakorpi, A. \& Jóhannsdóttir, G. \& Geirsdóttir, G. (2013). The usefulness of quality assurance for university management and academic staff: A case study of Finland and Iceland. European Journal of Higher Education 3(2), 1-14. Retrieved from http://www.tandfonline.com/doi/abs/10.1080/21568235.2013.772353.

Hughes, R. (2008). Internationalization of higher education and language policy. Questions of quality and equity. Higher Education Management and Policy, 20(1), 111-128.

Hultgren, K. (2013). Parallelsproglighed på danske universiteter. En statusrapport 2013. Retrieved from http://nordiskparallelsprogsnet.blogs.ku.dk/publikationer/landerapporter/.

Ikenberry, S.O. (2009). Privatizing the public research university. In C.C. Morphew and P. D. Eckel (Eds.), Privatizing the Public University: Perspectives from Across the Academy (pp. 1-6).

Baltimore: John Hopkins University Press.

Jacobsson, B. \& Lægreid, P. \& Pedersen, O. (2003). Europeanization and Transnational States: Comparing Nordic Central Governments. Milton Park: Routledge, Taylor \& Frances. 
Jalava, M. (2012). The university in the making of the welfare state. The 1970s degree reform in Finland. Frankfurt am Main: Peter Lang.

Kachru, B. (1997). World Englishes and English-using communities. Annual Review of Applied Linguistics, 17 (66-87).

Kallo, J. (2009). OECD education policy. A comparative and historical study focusing on the thematic reviews of tertiary education. Jyväskylä: Finnish Educational Research Association FERA.

Kröger, S. (2009). The Open Method of Coordination: Underconceptualisation, overdetermination, depoliticisation and beyond. In: S. Kröger (Ed.): What we have learnt: Advances, pitfalls and remaining questions in OMC research. European Integration online Papers (EIoP), Special Issue 1, 13, Art. 5, http://eiop.or.at/eiop/texte/2009-005a.htm.

Manley, T. J. and Hobby, S.M. (2004). Globalization of work: offshore outsourcing in the IT age. Fall 18. Emory International Law Review, 18(2), 401-420.

Marginson, S. (2006). Dynamics of national and global competition in higher education. Higher Education, 52(1), 1-39.

Marginson, S., \& van der Wende, M. C. (2009). Globalization and higher education. In Higher education to 2030. Volume 2: Globalisation (pp. 17-54). OECD. Paris: Organisation for Economic Co-operation and Development. Retrieved from http://cyber.law.harvard.edu/communia2010/sites/communia2010/images/OECD_2009_Higher_Ed ucation_to_2030_Volume_2_Globalisation.pdf\#page=19. 
Ministry of Education and Culture 2013. Korkeakoulujen lukukausimaksukokeilun seuranta ja arviointi. Työryhmän väliraportti III. 11.2.2013. [Follow-up and evaluation of Finnish higher education study fee experiment. Mid-term report III.] Ministry of Education. Retrieved from http://www.minedu.fi/export/sites/default/OPM/Koulutus/artikkelit/lukukausimaksukokeilu/liitteet/ Lukukausimaksukokeilun_valiraportti_III-Final.pdf

Newman, J., Barnes, M., Sullivan, H. \& Knops, A. (2004). Public Participation and Collaborative Governance. Journal of Social Policy, 33(2), 203-223.

Nordic Council of Ministers 2013. Tuition fees for international students. Nordic practice. TemaNord 2013:516. Copenhagen: Nordic Council of Ministers. http://dx.doi.org/10.6027/TN2013-516

Rinne, R., Jauhiainen, A., Simola, H., Lehto, R., Jauhiainen, A. \& Laiho, A. (2012), Valta, uusi yliopistopolitiikka ja yliopistotyö Suomessa. Kasvatusalan julkaisuja 58. Jyväskylä: Suomen kasvatustieteellinen seura.

Rodrik, D. (2011). The globalization paradox. Democracy and the future of the World economy. New York: W.W. Norton \& Company.

Rontu, H. \& Saarinen, T. (2013). University language policies: How does Finnish mono- or bilingualism meet academic multilingualism? Paper presented at the AFinLA Symposium, November 14-16, Turku, Finland. 
Rothstein, B. \& Uslaner, E. (2005). All for All: Equality, Corruption, and Social Trust. World Politics 58(1), 41-72.

Saarinen, T. (2008). Whose quality? Social actors in the interface of transnational and national higher education policy. Discourse: Studies in the Cultural Politics of Education, 29(2), 179-193.

Saarinen, T. (2012) Internationalization of Finnish higher education is language an issue? International Journal of the Sociology of Language, 216, 157-173.

Saarinen, T. (forthcoming) Language ideologies in Finnish higher education in the national and international context: a historical and contemporary outlook. In A.-K- Hultgren, F. Gregersen \& J. Thogersen (eds.) English in Nordic Academia: Ideology and Practice. Studies in World Language Problems. Benjamins.

Saarinen, T. \& Nikula, T. (2013). Implicit policy, invisible language: Policies and practices of international degree programmes in Finnish higher education. In A. Doiz, D. Lasagabaster, \& J. Sierra (Eds.), English-Medium Instruction at Universities: Global Challenge (pp. 131-150). Bristol: Multilingual Matters.

Saarinen, T. \& Pöyhönen, S. (2009). How national is national? Language education policy in a globalised world. Paper presented at the Language Policy and Language Learning conference, Limerick, June 18-20 2009.

Saarinen, T. \& Taalas, P. (forthcoming) Nordic language policy or policies for higher education? Higher Education (forthcoming 2014) 
Scott, P. (2011). The university as a global institution. In R. King, S. Marginson and R. Naidoo (Eds.) Handbook on globalization and higher education (pp. 59-75). Cheltenham: Edward Elgar.

Serrano-Velarde, K. (2008). Quality Assurance in the European higher education area: the emergence of a German market for quality assurance agencies. Higher Education Management and Policy (OECD) 20(3), 1-18.

Teichler, U. (2004). The changing debate on internationalisation of higher education. Higher Education 48, (5-26).

Veiga, A. \& Amaral, A. (2006). The open method of coordination and the implementation of the Bologna process. Tertiary Education Management 12, 283-295.

Välimaa, J. (2005). Social Dynamics of Higher Education Reforms. In Å. Gornitzka, M. Kogan \& A. Amaral (Eds.) Reform and change in higher education. Analysing policy implementation. (pp. 245-268). Dordrecht: Springer.

Weimer, L. (2012). Tuition fees for international students in Finland: A case study analysis of collective action and social change. PhD Dissertation, University of Georgia. 